\title{
The Current Status and Future Outlook of Quantum Dot-Based Biosensors for Plant Virus Detection
}

\author{
Sungyeap Hong and Cheolho Lee* \\ Department of Chemical and Biological Engineering, Seokyeong University, Seoul 02713, Korea \\ (Received on August 22, 2017; Revised on January 14, 2018; Accepted on January 18, 2018)
}

Enzyme-linked immunosorbent assay (ELISA) and polymerase chain reaction (PCR), widely used for the detection of plant viruses, are not easily performed, resulting in a demand for an innovative and more efficient diagnostic method. This paper summarizes the characteristics and research trends of biosensors focusing on the physicochemical properties of both interface elements and bioconjugates. In particular, the topological and photophysical properties of quantum dots (QDs) are discussed, along with QD-based biosensors and their practical applications. The QD-based Fluorescence Resonance Energy Transfer (FRET) genosensor, most widely used in the biomolecule detection fields, and QD-based nanosensor for Rev-RRE interaction assay are presented as examples. In recent years, QDbased biosensors have emerged as a new class of sensor and are expected to open opportunities in plant virus detection, but as yet there have been very few practical applications (Table 3). In this article, the details of those cases and their significance for the future of plant virus detection will be discussed.

Keywords : detection of plant virus, interface particle, quantum dot-based biosensors

Handling Associate Editor : Lim, Hyoun-Sub

\footnotetext{
*Corresponding author.

Phone) +82-2-940-7188

E-mail)chlee1219@hanmail.net

(c) This is an Open Access article distributed under the terms of the Creative Commons Attribution Non-Commercial License (http:// creativecommons.org/licenses/by-nc/4.0) which permits unrestricted noncommercial use, distribution, and reproduction in any medium, provided the original work is properly cited.
}

Articles can be freely viewed online at www.ppjonline.org.
The importance of diagnosis in the prevention of plant virus disease cannot be overemphasized. As the number of new plant viruses emerging increases due to climate change and expansion of trade in agricultural products, prevention of plant viruses by diagnosis is thought to be of critical importance. Since enzyme-linked immunosorbent assay (ELISA) or polymerase chain reaction (PCR), which are widely used for the detection of plant viruses, utilize specific antibodies or genes derived from the target virus, only the specific virus can be identified by these tests. This results in an inability to detect viruses that are beyond this range or which are newly emerging. In addition, the current ELISA and PCR diagnosis are expensive, time-consuming and require complex instruments and reagents. For these reasons, it is difficult to apply them on-site other than in specialized diagnostic institutions, so the development of a new diagnostic method with fewer limitations has been explored in various ways (Lopez et al., 2009). The recently developed loop mediated isothermal amplification (LAMP) is a technique that compensates for the disadvantages of the existing PCR-based method and is known to be able to rapidly amplify target genes with high specificity and sensitivity (Dhama et al., 2014; Notomi et al., 2000; Sakurai and Shibasaki, 2012).

On the other hand, fluorescent proteins, due to the advantages of easy observation and non-toxicity, are used in various fields such as membrane trafficking, detection of plant viruses, and quantitative analysis of gene expression (Berg and Beachy, 2008; Chalfie et al., 1994; Gerdes and Kaether, 1996; Misteli and Spector, 1997; Zimmer, 2002). However, since the fluorescent protein is an organic fluorophore with a narrow excitation wavelength range, there is a limitation in the light source used and there is a disadvantage that many fluorescent probes cannot be used at the same time because of their wide emission spectra. These also exhibit the following significant weaknesses; they are affected by various chemical metabolites in vivo, cause 
interference with their own fluorescent substances in plant cells and photobleaching reduces signal intensity rapidly in a short time (Berg and Beachy, 2008; Chudakov et al., 2010).

Nanotechnology, heralded as one of the core technologies of the future in the 2000 s, exerts omnidirectional influence across all industries, and the biosensor field is no exception. The development of various biosensors using nanoparticles can be said to be typical examples of this effect. In particular, the semiconductor nanoparticles such as quantum dots (QDs) have excellent optical properties. QDs are size-tunable and relatively resistant to photobleaching seen in conventional organic dyes as well as having the potent intensity of emitted light, bringing about an innovation in optical imaging fields including biosensors (Algar et al., 2010; Martín-Palma et al., 2009; Wegner and Hildebrandt, 2015).

Although quantum dot-based biosensors (QD-based biosensors) have been applied in the life sciences for about five years for the detection of human pathogenic viruses, fungi, and harmful foodborne bacteria (Chan et al., 2002; Shamsipur et al., 2017; Sharma et al., 2015), they have not been applied to the field of plant virus detection until recently, with only a few cases in the published literature (Khater et al., 2017). It is therefore the aim of this paper to examine the current state of QD-based biosensors for the detection of plant viruses and to make predictions concerning their use in the future.

\section{What are Biosensors?}

The term biosensor refers to a device designed to measure the presence and amount of a specific biological substance by combining a mechanism that converts the physicochemical changes appearing in response to the analytes present in the sample with a receptor that can manifest this as a recognizable signal (Scheller et al., 2001). Due to their ability to selectively and rapidly detect only the substances to be analyzed, biosensors are actively used in many industrial fields such as medical diagnosis, development of new drugs, plant pathology, food safety testing, and environmental monitoring (van Dorst et al., 2010; Mello and Kubota, 2002; Rodriguez-Mozaz et al., 2006). Furthermore the development of key supporting elements such as various interfaces and nanotechnology have extended the application range of biosensors to point-of-care tests (POCT) and the Internet-of-things (IoT) (Ohashia and Osaka, 2017; Soper et al., 2006).

Biosensors can be classified according to the type of interface element, the labeling substance and the signal converter (Monošík et al., 2012). Typical examples include surface plasmon resonance (SPR) generated on metal surfaces, quartz crystal microbalance (QCM) due to the mass change of biomolecules, the refractive index change due to the bending phenomenon of the cantilever, and the fluorescence change due to fluorescence resonance energy transfer (FRET) (Baller et al., 2000; Batchelor-McAuley et al., 2009; Kairdolf et al., 2013; Yuqing et al., 2003). The advantages, disadvantages, and research trends of these representative biosensors are summarized in Table 1.

Fluorescent biosensors have excellent sensitivity and simplicity and do not require expensive equipment, but interference due to biomaterials and short fluorescence persistence have been pointed out as disadvantages (Turner, 2013). However, recently they are facing a new turning point as they are combined with nanomaterials such as quantum dots or graphene quantum dots (GQDs) (Algar et al., 2010; Kairdolf et al., 2013; Shen et al., 2012).

\section{Quantum Dots and QD-Based Biosensors}

Quantum dots (QDs) are semiconductor nanocrystals with

Table 1. Characteristics and research trends of biosensors

\begin{tabular}{lllll}
\hline \multicolumn{1}{c}{ Technology } & \multicolumn{1}{c}{ Advantages } & \multicolumn{1}{c}{ Disadvantages } & Development trends & \multicolumn{1}{c}{ Remarks } \\
\hline $\begin{array}{l}\text { SPR } \\
\text { Biosensor }\end{array}$ & $\begin{array}{l}\text { Real-time analysis } \\
\text { possible }\end{array}$ & Better sensitivity required & Currently prevailing & $\begin{array}{l}\text { Gold nanoparticles and AFM* } \\
\text { applied research in progress }\end{array}$ \\
QCM & $\begin{array}{l}\text { Real-time analysis } \\
\text { possible }\end{array}$ & Better sensitivity required & Replaced by SPR & - \\
Biosensor & $\begin{array}{l}\text { Real-time analysis } \\
\text { possible }\end{array}$ & $\begin{array}{l}\text { Trouble of reproducibility and } \\
\text { measurement errors }\end{array}$ & Just beginning & In progress at the research \\
biosensor & Good sensitivity & $\begin{array}{l}\text { Fluorescent labeling required } \\
\text { and dynamic analysis impossible }\end{array}$ & $\begin{array}{l}\text { Already } \\
\text { commercialized }\end{array}$ & $\begin{array}{l}\text { Ongoing as a method for } \\
\text { detecting major biomolecules }\end{array}$ \\
\hline
\end{tabular}

*Atomic force microscope. 
unique photophysical properties and are comprised of elements from the periodic groups II-VI, III-V or IV-VI. As nanostructured materials, QDs are also known as zerodimensional materials. Cd-chalcogenide nanocrystals, one of the most typical QDs, consist of a core composed of a centrosome of about 2-10 nm and a shell composed of $\mathrm{ZnS}$. When coated with a polymer on the outer surface of the shell, they usually have a size of 10-15 nm. CdSe, CdTe, and $\mathrm{CdS}$ are mainly used as the centrosome of quantum dots (Algar et al., 2010).

QDs have unique photophysical properties that other materials do not have. Compared to traditional fluorescent probes such as organic dyes and fluorescent proteins, QDs have special optical and electronic properties such as narrow and symmetric emission spectra, broad absorption spectra that enable the simultaneous excitation of multiple fluorescent colors and size-tunable light emissions. QDs are also remarkably brighter and more resistant to photobleaching than other materials (Jamieson et al., 2007; Kairdolf et al., 2013; Kuang et al., 2011; Wegner and Hildebrandt, 2015).

A biosensor using QDs as an interface element is called a quantum dot-based biosensor. QD-based biosensors have been named according to the type of molecular beacon conjugated on QDs and transduction signals; QD-based FRET genosensor, QD-based FRET immunosensor, and QD-based Bioluminescence Resonance Energy Transfer (BRET) immunosensor, etc. (Ishikawa-Ankerhold et al., 2012; Resch-Genger et al., 2008; Vinayaka and Thakur, 2011). The schematic principle of QD-based FRET geno-

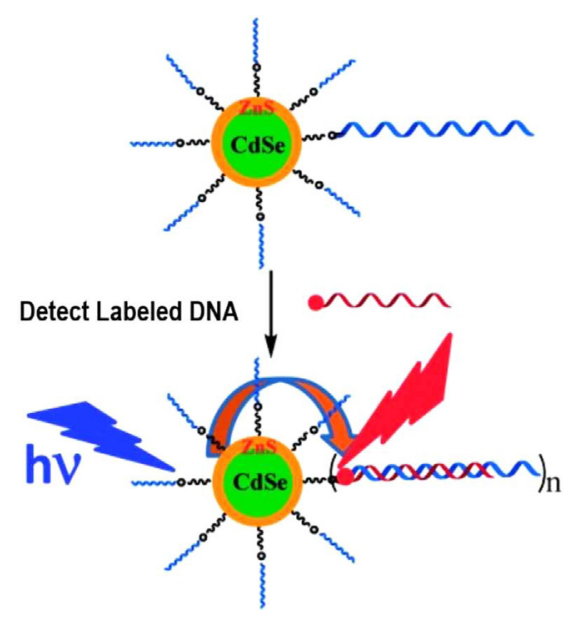

Fig. 1. Schematic QD-based FRET genosensor. Hybridization of a complementary dye-labelled DNA probe with the QD-DNA conjugate leads to QD sensitized dye FRET signals as a readout for labelled DNA detection (Reproduced by courtesy of Zhang et al., 2013a).

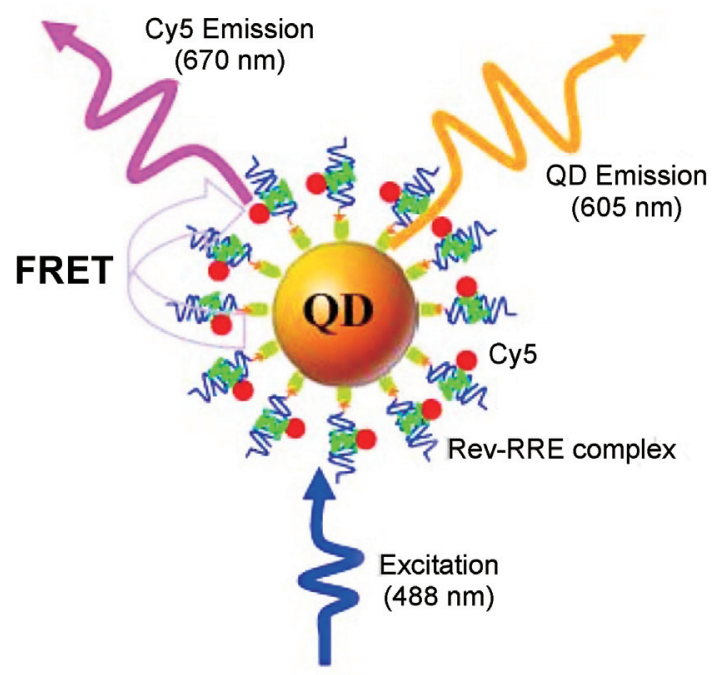

Fig. 2. QD-based FRET genosensor for Rev-RRE interaction assay based on FRET (Reproduced by courtesy of Zhang and Johnson, 2006).

sensor, widely used in biological applications, is shown in Fig. 1.

Zhang and Johnson (2006) reported a QD-based nanosensor for Rev-RRE interaction assay based on FRET between QD605 and Cy5 (Fig. 2). Rev is an important HIV1 regulatory protein that binds the Rev responsive element (RRE) within the env gene of HIV-1 RNA genome; the binding of Rev to RRE is essential for HIV replication. The nucleotide sequence, 5'-GGUCUGGGCGCAGCGCAAGCUGACGGUACAGGCC, where the sequence identified as important for Rev binding shown in italics and Cy5-labelled peptide (TRQARRNRRRRWRERQR) were used for biotinylation and the probe, respectively. The binding of a Cy5-labeled Rev to a biotinylated RRE IIB RNA formed a Rev-RRE complex, which was caught on the surface of a QD605 to form a QD605/RRE-Rev/ Cy5 assembly through specific streptavidin-biotin binding. FRET occurred between the QD605 and Cy5 upon illumination of the QD605/RRE-Rev/Cy5 assemblies with an excitation wavelength of $488 \mathrm{~nm}$.

Recently, QD-based sensors have been emerging as a new class of sensor, because they can be both labeled and label-free. They are being applied in various fields for monitoring of environmental pollution indicators as well as detecting of human pathogenic viruses and harmful foodborne bacteria (Adegoke et al., 2016; Vinayaka and Thakur, 2010).

\section{Detection of Plant Viruses Using Biosensors}

Biosensors for the detection of plant viruses are classified 
Table 2. Detection of plant viruses by SPR-based biosensors

\begin{tabular}{llll}
\hline Virus & \multicolumn{1}{c}{ Conjugate } & \multicolumn{1}{c}{ LOD* } & \multicolumn{1}{c}{ Reference } \\
\hline PVY & Monoclonal antibody & $0.31 \mathrm{mg} / \mathrm{ml}^{\dagger}$ & Gutierrez-Aguirre et al., 2014 \\
MCMV & Anti-MCMV antibody & $1 \mathrm{ng} / \mathrm{ml}$ & Zeng et al., 2013 \\
BSMV & Specific oligonucleotide from RNA- $\alpha$ & $14.7 \mathrm{ng} / \mathrm{ml}$ & Florschütz et al., 2013 \\
ASPV & DNA aptamer derived from coat protein & $500 \mathrm{mg} / \mathrm{ml}$ of total protein & Lautner et al., 2010 \\
CPMV & Monoclonal antibody & $16 \mathrm{mg} / \mathrm{ml}$ & Dubs et al., 1992 \\
\hline
\end{tabular}

${ }^{*}$ Limit of detection, ${ }^{\dagger} 1$ order of magnitude less sensitive than ELISA.

into interface elements and bioconjugates. QCM, SPR, and FRET phenomena are used as physicochemical properties of the interface element (Khater et al., 2017). The specific nucleotides, antibody, or monoclonal antibody derived from viruses, and their aptamer or motif are used for bioconjugation (Candresse et al., 2007; Lautner et al., 2010). Since Eun et al. (2002) reported on a QCM-based genosensor for the detection of cymbidium mosaic potexvirus (CymMV) and odontoglossum ringspot tobamovirus (ORSV), a number of biosensors for the detection of plant viruses combining various bioconjugates with different interface elements have been developed (Florschütz et al., 2013; Sun et al., 2008).

The SPR biosensors have been extensively studied as biosensors for the detection of plant viruses; the potato virus Y (PVY) (Gutierrez-Aguirre et al., 2014), apple stem pitting virus (ASPV) (Lautner et al., 2010), maize chlorotic mottle virus (MCMV) (Zeng et al., 2013), barley stripe mosaic virus (BSMV) (Florschütz et al., 2013), and cowpea mosaic virus (CPMV) (Dubs et al., 1992). The details of SPR-based biosensors for detection of plant viruses are summarized in Table 2.

The biosensors' reaction times for detecting plant viruses are mostly within a few minutes, which is significantly faster than either ELISA or PCR. However, detection limits vary significantly depending on the interface particle, bioconjugate and target virus, ranging from several tens of $\mathrm{pg} / \mathrm{ml}$ to several tens of $\mu \mathrm{g} / \mathrm{ml}$. In fact, Eun et al. (2002) reported the detection limits of QCM-DNA sensor of two plant viruses of CymMV and ORSV as $1 \mathrm{ng} / \mathrm{ml}$ and $10 \mathrm{ng} /$ $\mathrm{ml}$ for RNA and vegetable sap, respectively. Meanwhile Dickert et al. (2004) reported the detection limit of QCM biosensor labeled with a TMV antibody as $100 \mathrm{ng} / \mathrm{ml}$ to $1 \mu \mathrm{g} / \mathrm{ml}$. Malecka et al. (2014) reported that the detection limit of PPV was $12.8 \mathrm{pg} / \mathrm{ml}$, using an ion-channel genosensor labeled with Plum Pox Virus (PPV)-derived 22mer and 42-mer complementary ssDNA. Lin et al. (2014) reported that the detection time of a fiber optic particle plasmon resonance (FOPPR) immunosensor was within 10 minutes, and the detection limits of CymMV and ORSV were $48 \mathrm{pg} / \mathrm{ml}$ and $42 \mathrm{pg} / \mathrm{ml}$, respectively, which is tens of times higher than the $1.2 \mathrm{ng} / \mathrm{ml}$ of ELISA. In addition, McClellan et al. (2012) reported that the detection limit and the detection time of bean pod mottle virus (BPMV) using silicon photonic microring resonator (SPMR) were $10 \mathrm{ng} / \mathrm{ml}$ and $45 \mathrm{~min}$, respectively, which is slightly higher and slightly shorter than that of ELISA. Florschütz et al. (2013) reported that the detection limit of the SPR sensor labeled with the specific oligonucleotide of BSMV RNA- $\alpha$ was $14.7 \mathrm{ng} / \mathrm{ml}$ in infected plant sap. On the other hand, Gutiérrez-Aguirre et al. (2014) reported that the detection limit of the SPR sensor labeled with a monoclonal antibody derived from PVY coat protein was $0.31 \mu \mathrm{g} / \mathrm{ml}$, which is tens of times less sensitive than the $0.019 \mu \mathrm{g} / \mathrm{ml}$ of ELISA. Based on these results, it can be suggested that the interface element selection is very important.

The detection limits were also reported to vary depending on the target virus. In fact, Dubs et al. (1992) reported that the detection limit of the SPR sensor labeled with a monoclonal antibody derived from CPMV coat protein was 16 $\mu \mathrm{g} / \mathrm{ml}$, which is tens of times less sensitive than the PVY detection limit $(0.31 \mu \mathrm{g} / \mathrm{ml})$ of the SPR sensor reported by Gutiérrez-Aguirre et al (2014).

Nucleic acids tend to be preferred as the most useful tool to mediate various physicochemical phenomena of interface particles because of their specificity among bioconjugates irrespective of biosensor interface element. As shown in Table 2, this seems to result from the fact that the detection limit of the biosensor labeled with nucleic acids as a probe is up to tens of thousands times more sensitive than that of the biosensor labeled with proteins such as antibodies or monoclonal antibodies.

Meanwhile, many investigations have revealed that the detection limit of the biosensors for plant viruses is more sensitive as the size of bioconjugate is smaller. This can be seen from the fact that the detection limit of the sensor labeled with a specific sequence of the gene or its aptamer is generally more sensitive than that of the sensor labeled with the antibody derived from the viral coat protein (Florschütz et al., 2013; Zeng et al., 2013). However, these 
Table 3. Detection of plant viruses by QD-based biosensors

\begin{tabular}{|c|c|c|c|c|}
\hline Virus & Interface & Conjugate & LOD* & Reference \\
\hline $\mathrm{CPMV}^{2}$ & CdSe-ZnS core & Surface-immobilized CPMV & - & Medintz et al., 2005 \\
\hline CaMV & $\mathrm{PbS}$ nanoparticle & 23-mer derived from CaMV $35 \mathrm{~S}$ & $4.38 \times 10^{-12} \mathrm{~mol} / \mathrm{l}$ & Sun et al., 2008 \\
\hline $\mathrm{CTV}$ & $\mathrm{InP}$ & Antibody to CTV coat protein & $2 \mathrm{nM}$ for antibody & Moreau et al., 2012 \\
\hline CTV & $\mathrm{CdTe}$ & CTV-CP antibody & $220 \mathrm{ng} / \mathrm{ml}$ & Shojaei et al., 2016b \\
\hline CTV & AuNPs/QD & AuNPs-CTV-CP/QDs-CTV-CP antibody & $130 \mathrm{ng} / \mathrm{ml}^{3}$ & Shojaei et al., 2016a \\
\hline CTV & CdTe & CTV-CP antibody & $198 \mathrm{ng} / \mathrm{ml}$ & Safarnejad et al., 2017 \\
\hline GVA & $\mathrm{ZnO}$ films & Grapevine virus A-type proteins & $1 \mathrm{pg} / \mathrm{ml}-10 \mathrm{ng} / \mathrm{ml}$ & Tereshchenko et al., 2017 \\
\hline $\begin{array}{l}\text { ToRSV, BPMV } \\
\text { \& ArMV }\end{array}$ & $\begin{array}{l}\mathrm{Fe}_{3} \mathrm{O}_{4} / \mathrm{SiO}_{2} \mathrm{MNPs} \\
\& \mathrm{SiO}_{2} / \mathrm{UCNPs}^{4}\end{array}$ & Antibody & $100 \mathrm{ng} / \mathrm{ml}$ & Zhang et al., 2013b \\
\hline
\end{tabular}

*Limit of detection

are comparisons between different viral systems, so more research using the specific gene and antibody derived from the same virus would be needed for the precise measurement of the sensitivity between them.

Recently, quantum dot-based biosensors have been extensively studied in the field of human viruses (Adegoke et al., 2016; Shamsipur et al., 2017; Shen and Gao, 2015) because not only do quantum dots not require the expensive equipments that SPR or electrochemical biosensors do, but they can also reduce the non-specificity due to their own fluorescent material in the host cell. However, their application to the field of plant virus detection has only begun recently and only a very few cases have been reported (Khater et al., 2017). Medintz et al. (2005) labeled the CdSe quantum dots with histidine and lysine, the main constituent amino acids of CPMV coat protein. Sun et al. (2008) discussed the sensor labeled with the 23-mer oligonucleotide derived from the CaMV $35 \mathrm{~S}$ promoter on a $\mathrm{PbS}$ nanoparticle. Investigations into the sensor labeled with the antibody derived from CTV coat protein on CdTe QDs (Safarnejad et al., 2017; Shojaei et al., 2016a) and the sensor labeled with the GVA antibody derived from GVA coat protein on the $\mathrm{ZnO}$ films (Tereshchenko et al., 2017) have followed. The details of QD-based biosensors for the detection of plant viruses are summarized in Table 3.

Citrus tristeza virus (CTV) was the most extensively researched. The sensor, labeled with a CTV coat proteinderived antibody on the CdTe quantum dot, is a representative example (Safarnejad et al., 2017; Shojaei et al., 2016b; Moreau et al., 2012). In fact, using antibody derived from CTV coat protein, alternative types of biosensors were reported to enhance the specificity and sensitivity of fluorescence resonance energy transfer (FRET)-based biosensor. Shojaei et al. (2016a) reported the complex sensor using the mixture of CdTe quantum dots and gold nanoparticles (AuNPs) labeled with an antibody derived from CTV coat

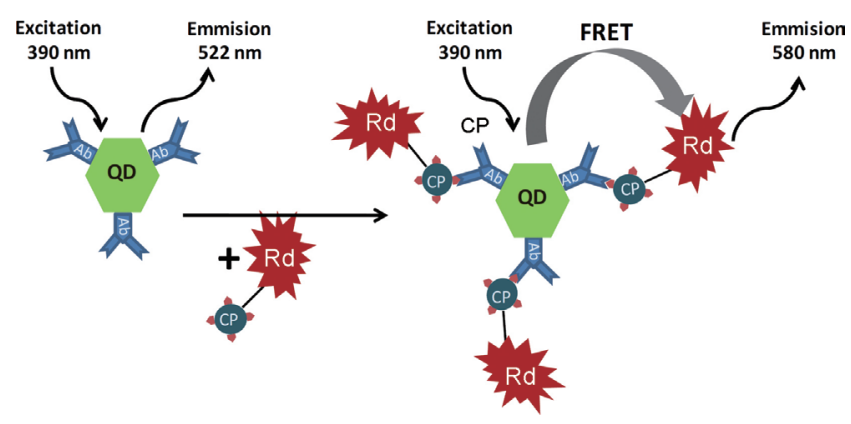

Fig. 3. Schematic presentation of specific CTV nanobiosensor (Reproduced by courtesy of Safarnejad et al., 2017).

protein. Safarnejad et al. (2017) reported on the donoracceptor complex sensor; QDs conjugated with antibody derived from CTV coat protein and rhodamine 123 conjugated with the recombinant coat protein of the CTV were used as donor and acceptor, respectively (Fig. 3).

Conversely, Zhang et al. (2013b) reported that mixed infections can be detected at a limit of $100 \mathrm{ng} / \mathrm{ml}$ by reacting magnetic nanoparticles (MNPs) and upconversion nanoparticles (UCNPs) in sandwich form (Fig. 4). $\mathrm{Fe}_{3} \mathrm{O}_{4} /$ $\mathrm{SiO}_{2}$ MNPs $(\sim 100 \mathrm{~nm})$ were labeled with different anti-

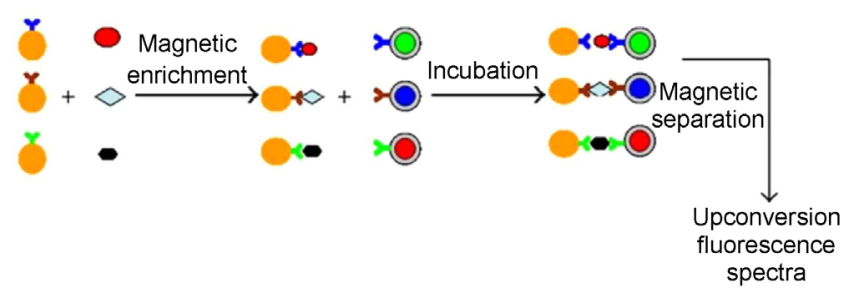

$\succ \succ$ Different antibody-conjugated $\mathrm{SiO}_{2} / \mathrm{Fe}_{3} \mathrm{O}_{4} \mathrm{MNPs}$

$\gamma \gamma$ Different antibody-conjugated $\mathrm{SiO}_{2} /$ UCNPs

$\checkmark$. Different kinds of plant virus

Fig. 4. Schematic presentation of immunomagnetic separation and fluorescence detection of target viruses in sandwich-type system (Reproduced by courtesy of Zhang et al., 2013b). 
bodies derived from coat protein of ToRSV, BPMV and ArMV and employed to capture and enrich the target viruses. Then $\mathrm{SiO}_{2} \mathrm{UCNPs}$ conjugated with specific antibodies as signal probes were added to form sandwich complexes.

\section{Concluding Remarks}

This paper aims to both outline the characteristics of biosensors according to the physicochemical properties of interface elements and bioconjugates, and review the related research trends in the field. The topological and unique photophysical properties of quantum dots (QDs) and QDbased biosensors using quantum dots (QDs) as an interface element are also discussed. A QD-based nanosensor for Rev-RRE interaction assay (Zhang and Johnson, 2006) is presented as one of the practical applications.

In the field of plant virus detection, the utility of SPR biosensors for major plant viruses including TMV, PVY, MCMV and BSMV have been extensively researched. Even though there are relatively few studies of plant virus detection by QD-based biosensors compared to the active research in the human virus detection field, several cases have been reported (Table 3). It is believed that the evidence reviewed here strongly suggests that QDs have specific characteristics which make them particularly suited to the detection of plant viruses.

QDs, compared to conventional organic dyes and fluorescent proteins, have unique photophysical properties such as narrow and symmetric emission spectra, broad absorption spectra that enable the simultaneous excitation of multiple fluorescent colors, size-tunable light emission and resistance to photobleaching (Kairdolf et al., 2013; Wegner and Hildebrandt, 2015). Even though the application of QD-based biosensors to the detection of plant viruses has been limited, if consideration is given to the unique photophysical properties of the quantum dots as an interface element, it can be expected that they will contribute to a future paradigm shift in the field of plant virus detection.

\section{Acknowledgments}

This work was supported by Seokyeong University in 2016.

\section{References}

Adegoke, O., Seo, M., Kato, T., Kawahito, S. and Park, E. Y. 2016. An ultrasensitive $\mathrm{SiO}_{2}$-encapsulated alloyed $\mathrm{CdZnSeS}$ quantum dot-molecular beacon nanobiosensor for norovirus. Biosens. Bioelectron. 86:135-142.
Algar, W. R., Tavares, A. J. and Krull, U. J. 2010. A review of the application of quantum dots as integrated components of assays, bioprobes, and biosensors utilizing optical transduction. Anal. Chim. Acta 673:1-25.

Baller, M. K., Lang, H. P., Fritz, J., Gerber, C., Gimzewski, J. K., Drechsler, U., Rothuizen, H., Despont, M., Vettiger, P., Battiston, F. M., Fornaro, P., Meyer, E. and Guntherodt, H. J. 2000. A cantilever array-based artificial nose. Ultramicroscopy 82:1-9.

Batchelor-McAuley, C., Wildgoose, G. G. and Compton, R. G. 2009. The physicochemical aspects of DNA sensing using electrochemical methods. Biosens. Bioelectron. 24:31833190.

Berg, R. H. and Beachy, R. N. 2008. Fluorescent protein applications in plants. Methods Cell Biol. 85:153-177.

Candresse, T., Lot, H., German-Retana, S., Krause-Sakate, R., Thomas, J., Souche, S., Delaunay, T., Lanneau, M. and le Gall, O. 2007. Analysis of the serological variability of lettuce mosaic virus using monoclonal antibodies and surface plasmon resonance technology. J. Gen. Virol. 88:2605-2610.

Chalfie, M., Tu, Y., Euskirchen, G., Ward, W. W. and Prasher, D. C. 1994. Green fluorescent protein as a marker for gene expression. Science 263:802-805.

Chan, W. C. W., Maxwell, D. J., Gao, X., Bailey, R. E., Han, M. and Nie, S. 2002. Luminescent quantum dots for multiplexed biological detection and imaging. Curr. Opin. Biotechnol. 13:40-46.

Chudakov, D. M., Matz, M. V., Lukyanov, S. and Lukyanov, K. A. 2010. Fluorescent proteins and their applications in imaging living cells and tissues. Physiol. Rev. 90:1103-1163.

Dhama, K., Karthik, K., Chakraborty, S., Tiwari, R., Kapoor, S., Kumar, A. and Thomas, P. 2014. Loop-mediated isothermal amplification of DNA (LAMP): a new diagnostic tool lights the world of diagnosis of animal and human pathogens: a review. Pak. J. Biol. Sci. 17:151-166.

Dickert, F. L., Hayden, O., Bindeus, R., Mann, K. J., Blaas, D. and Waigmann, E. 2004. Bioimprinted QCM sensors for virus detection-screening of plant sap. Anal. Bioanal. Chem. 378:1929-1934.

Dubs, M. C., Altschuh, D. and van Regenmortel, M. H. V. 1992. Interaction between viruses and monoclonal antibodies studied by surface plasmon resonance. Immunol. Lett. 31:59-64.

Eun, A. J., Huang, L., Chew, F., Li, S. F. and Wong, S. 2002. Detection of two orchid viruses using quartz crystal microbalance-based DNA biosensors. Phytopathology 92:654-658.

Florschütz, K., Schröter, A., Schmieder, S., Chen, W., Schweizer, P., Sonntag, F., Danz, N., Baronian, K. and Kunze, G. 2013. 'Phytochip': on-chip detection of phytopathogenic RNA viruses by a new surface plasmon resonance platform. J. Virol. Methods 189:80-86.

Gerdes, H. and Kaether, C. 1996. Green fluorescent protein: applications in cell biology. FEBS Lett. 389:44-47.

Gutiérrez-Aguirre, I., Hodnik, V., Glais, L., Rupar, M., Jacquot, E., Anderluh, G. and Ravnikar, M. 2014. Surface plasmon reso- 
nance for monitoring the interaction of Potato virus $\mathrm{Y}$ with monoclonal antibodies. Anal. Biochem. 447:74-81.

Ishikawa-Ankerhold, H. C., Ankerhold, R. and Drummen, G. P. C. 2012. Advanced fluorescence microscopy techniques-FRAP, FLIP, FLAP, FRET and FLIM. Molecules 17:4047-4132.

Jamieson, T., Bakhshi, R., Petrova, D., Pocock, R., Imani, M. and Seifalian, A. M. 2007. Biological applications of quantum dots. Biomaterials 28:4717-4732.

Kairdolf, B. A., Smith, A. M., Stokes, T. H., Wang, M. D., Young, A. N. and Nie, S. 2013. Semiconductor quantum dots for bioimaging and biodiagnostic applications. Annu. Rev. Anal. Chem. (Palo Alto Calif.) 6:143-162.

Khater, M., de la Escosura-Muñiz, A. and Merkoçi, A. 2017. Biosensors for plant pathogen detection. Biosens. Bioelectron. 93:72-86.

Kuang, H., Zhao, Y., Ma, W., Xua, L., Wang, L. and Xu, C. 2011. Recent developments in analytical applications of quantum dots. Trends Analyt. Chem. 30:1620-1636.

Lautner, G., Balogh, Z., Bardoczy, V., Meszaros, T. and Gyurcsanyi, R. E. 2010. Aptamer-based biochips for label-free detection of plant virus coat proteins by SPR imaging. Analyst 135:918-926.

Lin, H. Y., Huang, C. H., Lu, S. H., Kuo, I. T. and Chau, L. K. 2014. Direct detection of orchid viruses using nanorod-based fiber optic particle plasmon resonance immunosensor. Biosens. Bioelectron. 51:371-378.

Lopez, M. M., Llop, P., Olmos, A., Marco-Noales, E., Cambra, M. and Bertolini, E. 2009. Are molecular tools solving the challenges posed by detection of plant pathogenic bacteria and viruses? Curr. Issues Mol. Biol. 11:13-46.

Malecka, K., Michalczuk, L., Radecka, H. and Radecki1, J. 2014. Ion-channel genosensor for the detection of specific DNA sequences derived from plum pox virus in plant extracts. Sensors 14:18611-18624.

Martín-Palma, R. J., Manso, M. and Torres-Costa, V. 2009. Optical biosensors based on semiconductor nanostructures. Sensors 9:5149-5172.

McClellan, M. S., Domier, L. L. and Bailey, R. C. 2012. Labelfree virus detection using silicon photonic microring resonators. Biosens. Bioelectron. 31:388-392.

Medintz, I. L., Sapsford, K. E., Konnert, J. H., Chatterji, A., Lin, T., Johnson, J. E. and Mattoussi, H. 2005. Decoration of discretely immobilized cowpea mosaic virus with luminescent quantum dots. Langmuir 21:5501-5510.

Mello, L. D. and Kubota, L. T. 2002. Review of the use of biosensors as analytical tools in the food and drink industries. Food Chem. 77:237-256.

Misteli, T. and Spector, D. L. 1997. Applications of the green fluorescent protein in cell biology and biotechnology. Nat Biotechnol. 15:961-964.

Monošík, R., Stred'anský, M. and Šturdík, E. 2012. Biosensorsclassification, characterization and new trends. Acta Chim. Slov. 5:109-120.

Moreau, A. L. D., Janissen, R., Santos, C. A., Peroni, L. A.,
Stach-Machado, D. R., de Souza, A. A., de Souza, A. P. and Cotta, M. A. 2012. Highly-sensitive and label-free indium phosphide biosensor for early phytopathogen diagnosis. Biosens. Bioelectron. 36:62-68.

Notomi, T., Okayama, H., Masubuchi, H., Yonekawa, T., Watanabe, K., Amino, N. and Hase, T. 2000. Loop-mediated isothermal amplification of DNA. Nucleic Acids Res. 28:e63.

Ohashia, K. and Osaka, T. 2017. Industrialization trial of a biosensor technology. ECS Trans. 75:1-9.

Resch-Genger, U., Grabolle, M., Cavaliere-Jaricot, S., Nitschke, R. and Nann, T. 2008. Quantum dots versus organic dyes as fluorescent labels. Nat. Methods 5:763-775.

Rodriguez-Mozaz, S., de Alda, M. J. L. and Barceló, D. 2006. Biosensors as useful tools for environmental analysis and monitoring. Anal. Bioanal. Chem. 386:1025-1041.

Safarnejad, M. R., Samiee, F., Tabatabie, M. and Mohsenifar, A. 2017. Development of quantum dot-based nanobiosensors against citrus tristeza virus (CTV). Sensors \& Transducers $J$. 213:54-60.

Sakurai, A. and Shibasaki, F. 2012. Updated values for molecular diagnosis for highly pathogenic avian influenza virus. Viruses 4:1235-1257.

Scheller, F. W., Wollenberger, U., Warsinke, A. and Lisdat, F. 2001. Research and development in biosensors. Curr. Opin. Biotechnol. 12:35-40.

Shamsipur, M., Nasirian, V., Mansouri, K., Barati, A., Veisi-Raygani, A. and Kashanian, S. 2017. A highly sensitive quantum dots-DNA nanobiosensor based on fluorescence resonance energy transfer for rapid detection of nanomolar amounts of human papillomavirus 18. J. Pharm. Biomed. Anal. 136:140147.

Sharma, A., Rao, K. V., Kamboj, D. V., Gaur, R., Upadhyay, S. and Shaik, M. 2015. Relative efficiency of zinc sulfide (ZnS) quantum dots (QDs) based electrochemical and fluorescence immunoassay for the detection of Staphylococcal enterotoxin B (SEB). Biotechnol. Rep. (Amst.) 6:129-136.

Shen, J., Zhu, Y., Yang, X. and Li, C. 2012. Graphene quantum dots: emergent nanolights for bioimaging, sensors, catalysis and photovoltaic devices. Chem. Commun. 48:3686-3699.

Shen, W. and Gao, Z. 2015. Quantum dots and duplex-specific nuclease enabled ultrasensitive detection and serotyping of Dengue viruses in one step in a single tube. Biosens. Bioelectron. 65:327-332.

Shojaei, T. R., Salleh, M. A. M., Sijam, K., Rahim, R. A., Mohsenifar, A., Safarnejad, R. and Tabatabaei, M. 2016a. Detection of Citrus tristeza virus by using fluorescence resonance energy transfer-based biosensor. Spectrochim. Acta A Mol. Biomol. Spectrosc. 169:216-222.

Shojaei, T. R., Salleh, M. A. M., Sijam, K., Rahim, R. A., Mohsenifar, A., Safarnejad, R. and Tabatabaei, M. 2016 b. Fluorometric immunoassay for detecting the plant virus Citrus tristeza using carbon nanoparticles acting as quenchers and antibodies labeled with CdTe quantum dots. Mikrochim. Acta 183:2277-2287. 
Soper, S. A., Brown, K., Ellington, A., Frazier, B., GarciaManeroe, G., Gauf, V., Gutman, S. I., Hayes, D. F., Kortei, B., Landers, J. L. and Larson, D. 2006. Point-of-care biosensor systems for cancer diagnostics/prognostics. Biosens. Bioelectron. 21:1932-1942.

Sun, W., Zhong, J., Qin, P. and Jiao, K. 2008. Electrochemical biosensor for the detection of cauliflower mosaic virus $35 \mathrm{~S}$ gene sequences using lead sulfide nanoparticles as oligonucleotide labels. Anal. Biochem. 377:115-119.

Tereshchenko, A., Fedorenko, V., Smyntyna, V., Konup, I., Konup, A., Eriksson, M., Yakimova, R., Ramanavicius, A., Balme, S. and Bechelany, M. 2017. ZnO films formed by atomic layer deposition as an optical biosensor platform for the detection of Grapevine virus A-type proteins. Biosens. Bioelectron. 92:763-769.

Turner, A. P. F. 2013. Biosensors: sense and sensibility. Chem. Soc. Rev. 42:3184-3196.

van Dorst, B., Mehta, J., Bekaert, K., Rouah-Martin, E., de Coen, W., Dubruel, P., Blust, R. and Robbens, J. 2010. Recent advances in recognition elements of food and environmental biosensors: a review. Biosens. Bioelectron. 26:1178-1194.

Vinayaka, A. C. and Thakur, M. S. 2010. Focus on quantum dots as potential fluorescent probes for monitoring food toxicants and foodborne pathogens. Anal. Bioanal. Chem. 397:14451455.

Vinayaka, A. C. and Thakur, M. S. 2011. Photoabsorption and resonance energy transfer phenomenon in CdTe-protein bioconjugates: an insight into QD-biomolecular interactions. Bioconjug. Chem. 22:968-975.

Wegner, K. D. and Hildebrandt, N. 2015. Quantum dots: bright and versatile in vitro and in vivo fluorescence imaging biosensors. Chem. Soc. Rev. 44:4792-4834.

Yuqing, M., Jianguo, G. and Jianrong, C. 2003. Ion sensitive field effect transducer-based biosensors. Biotechnol. Adv. 21:527534.

Zeng, C., Huang, X., Xu, J., Li, G., Ma, J., Ji, H. F., Zhu, S. and Chen, H. 2013. Rapid and sensitive detection of maize chlorotic mottle virus using surface plasmon resonance-based biosensor. Anal. Biochem. 440:18-22.

Zhang, C. and Johnson, L. W. 2006. Quantum-dot-based nanosensor for RRE IIB RNA-rev peptide interaction assay. J. Am. Chem. Soc. 128:5324-5325.

Zhang, H., Feng, G., Guo, Y. and Zhou, D. 2013a. Robust and specific ratiometric biosensing using a copper-free clicked quantum dot-DNA aptamer sensor. Nanoscale 5:1030710315.

Zhang, M., Chen, W., Chen, X., Zhang, Y., Lin, X., Wu, Z. and Li, M. 2013b. Multiplex immunoassays of plant viruses based on functionalized upconversion nanoparticles coupled with immunomagnetic separation. J. Nanomater. 2013:317437.

Zimmer, M. 2002. Green Fluorescent Protein (GFP): applications, structure, and related photophysical behavior. Chem. Rev. 102:759-782. 